\title{
Health literacy index in relation to drug information received from pharmacists
}

\author{
Niken Nur Widyakusuma ${ }^{1 *}$, Chairun Wiedyaningsih ${ }^{1}$, Bella Hazana ${ }^{1}$, Shirrin Shafira Azzahra ${ }^{1}$, Triyani Dinityaswati ${ }^{1}$, \\ and Nur Amalina Rozanah ${ }^{1}$ \\ ${ }^{1}$ Faculty of Pharmacy, Universitas Gadjah Mada, Yogyakarta, Indonesia
}

\begin{abstract}
Despite the significance of health literacy to health outcomes, there remains limited data on it in Indonesia, or whether drug information services provided by pharmacists can improve patients' health literacy. This study aimed to measure the health literacy indices of health care visitors in Yogyakarta, Indonesia, and to identify whether the amount of drug information received from pharmacists, among other factors, is a determinant of health literacy. The research was a cross-sectional study using the Health Literacy Survey-Europe-Asia-Questionnaire (HLS-EU-Asia-Q) that was distributed to 400 respondents in pharmacies, hospitals, and primary health centres in Yogyakarta City. The relationships between respondents' characteristics, including the amount of drug information received from pharmacists, and their health literacy index were analysed using Chi Square. Results: As many as $67.3 \%$ of respondents had limited health literacy index scores. There was evidence that the scores were relative to the amount of drug information they had received from pharmacists $(\mathrm{p} \leq 0.05)$. This study complements health literacy index data in Yogyakarta City, Indonesia, and provides evidence of potential health literacy determinants. Keywords: Health literacy, index, pharmacist, questionnaire
\end{abstract}

\section{Introduction}

Health literacy is key to the communication process between pharmacist and patient [1]. Pharmacists must be aware of the health literacy of their patients, as patients with limited background might have difficulties in accessing or processing drug information. Lack of drug information leads to poor medication adherence and poor health outcomes.

There are different opinions on whether health literacy is a dynamic or static condition [2], inasmuch as health literacy develops over time [3]. Some pharmacybased interventions to improve health literacy have been initiated and discussed [4, 5]. Yet, published interventions usually affect medication adherence or health outcomes, not necessarily the level of health literacy itself.

Instructions regarding medication can be provided through drug information. According to Regulation of Indonesian Health Minister Number 73/2016 (6), the pharmacist must provide the drug name, instructions for use, indication(s), side effects, possible interactions, expectations for medication, and storage. They must also offer suggestions or answers to patient questions regarding the medication(s), their health status, health management, healthy lifestyle and disease prevention, food to be consumed or avoided, how to choose the right medicines, physician control, and laboratory tests needed. However, many pharmacists convey only enough information for short use and this may affect the patient's health literacy.
As limited data on health literacy in Indonesia is available, this study aimed to measure the health literacy index in Yogyakarta City, as well as to identify whether and to what extent the amount of drug information received from pharmacists is a determinant of health literacy, among other factors such as sociodemographic. The amount of drug information was used as a proxy to drug information services received by patients.

\section{Materials and Methods}

This was a population-based, cross-sectional study. Purposive sampling based on inclusion-exclusion criteria was conducted during October and November 2016 to visitors of two pharmacies, one hospital, and one primary health care facility that serves Yogyakarta City. The target population was a minimum of $18 \mathrm{yr}$., residing in Yogyakarta City, and willing to participate in the research. Exclusion criteria were respondents who worked as health workers or had limited communication capacity. All questionnaires were reviewed with the respondents to ensure their completion. Four hundred respondents were considered representative for Yogyakarta City's nearly 418,000 residents in 2016.

The health literacy index was measured using HLSEU-Asia-Q Bahasa Indonesia version, while the amount of drug information received by respondents was determined from questionnaires adapted from the Regulation of Indonesian Health Minister Number $35 / 2016$ (which is now revised to 73/2016). HLS-EU-

*Corresponding author: niken.nur.w@ugm.ac.id 
Asia-Q was shown to have good construct validity, satisfactory goodness-of-fit of the data to the hypothetical model in three health literacy domains, high internal consistency (Cronbach's alpha > 0.90), satisfactory item-scale convergent validity (item-scale correlation $\geq 0.40$ ), and no floor/ceiling effects in six Asian countries [7]. Content validity and face validity of the Drug Information Questionnaire was tested with 40 non-sample respondents. The reliability test was the Cronbach alpha test. Analysis was performed using SPSS version 22. The health literacy index was classified as sufficient (score $\geq 34$ ) and limited (scor]e $<$ 33) [8], while the amount of drug information was also considered sufficient (score $61 \%$ to $100 \%$ ) and limited (score $\leq 60 \%$ ) [9]. Identification of potential determinants of health literacy, including the amount of drug information received by the respondents, was analyzed using Chi Square with $\alpha<0.05$ and considered significant. The research was granted ethics approval from The Medical and Health Research Ethics Committee (MHREC), Faculty of Medicine, Universitas Gadjah Mada, number KE/FK/1213/EC/2016.

\subsection{Data Sharing}

Research data for this study is available in Mendeley Data [22].

\section{Results}

Four hundred respondents completed 47 questions of HLS-EU-Asia-Q and 15 questions of a Drug Information Questionnaire. Participants' mean age was 36.28 y.o [13.25]. Characteristics of respondents, as well as their general health literacy index score, are shown in Table 1.

Table 1. Characteristics of Respondents $(N=400)$ and their general health literacy index score.

\begin{tabular}{|l|l|l|l|l|}
\hline & & & \multicolumn{2}{|c|}{$\begin{array}{c}\text { General Health } \\
\text { Literacy Indices }\end{array}$} \\
\cline { 4 - 5 } & $\mathrm{N}(\%)$ & $\begin{array}{l}\text { Missing } \\
\text { data (N) }\end{array}$ & $\begin{array}{l}\text { Sufficient } \\
(\mathrm{N}= \\
131)\end{array}$ & $\begin{array}{c}\text { Limited } \\
(\mathrm{N}= \\
269)\end{array}$ \\
\hline Female & $\begin{array}{l}236 \\
(59.0)\end{array}$ & 0 & $86(65.6)$ & $\begin{array}{l}150 \\
(55.8)\end{array}$ \\
\hline $\begin{array}{l}\text { Age } \geq 65 \\
\text { years }\end{array}$ & $7(1.8)$ & 4 & $2(1.5)$ & $5(1.9)$ \\
\hline $\begin{array}{l}\text { Lower } \\
\text { education }\end{array}$ & $\begin{array}{l}227 \\
(56.9)\end{array}$ & 1 & $67(51.1)$ & $\begin{array}{l}160 \\
(59.5)\end{array}$ \\
\hline $\begin{array}{l}\text { Lower } \\
\text { income }\end{array}$ & $\begin{array}{l}289 \\
(78.7)\end{array}$ & 33 & $96(79,3)$ & $\begin{array}{l}193 \\
(78.5)\end{array}$ \\
\hline $\begin{array}{l}\text { Having } \\
\text { long term } \\
\text { illness or } \\
\text { health } \\
\text { problems }\end{array}$ & $\begin{array}{l}206 \\
(51.5)\end{array}$ & 0 & $72(55.0)$ & $\begin{array}{l}134 \\
(49.8)\end{array}$ \\
\hline $\begin{array}{l}\text { Difficult to } \\
\text { pay for } \\
\text { medication }\end{array}$ & $\begin{array}{l}52 \\
(13.1)\end{array}$ & 2 & $11(8.4)$ & $\begin{array}{l}41 \\
(15.2)\end{array}$ \\
\hline $\begin{array}{l}\text { Limited } \\
\text { number of } \\
\text { drug }\end{array}$ & $\begin{array}{l}85 \\
(21.3)\end{array}$ & 0 & $17(13.0)$ & $\begin{array}{l}68 \\
(25.3)\end{array}$ \\
\hline
\end{tabular}

\begin{tabular}{|l|l|l|l|l|}
\hline $\begin{array}{l}\text { information } \\
\text { received* }\end{array}$ & & & & \\
\hline
\end{tabular}

* significant at $\mathrm{p}=0.04$

Limited health literacy index score was shown for 131 respondents $(67.3 \%)$, while the others' $(32.8 \%)$ index scores were sufficient. Of all respondents, the highest index of health literacy was 49.29 , while the lowest was 8.87 , with an average score of 31.2 and standard deviation of 4.9. The distribution of respondents' health literacy index scores is shown in Fig. 1, and the mean of each domain of health literacy score is shown in Table 2.

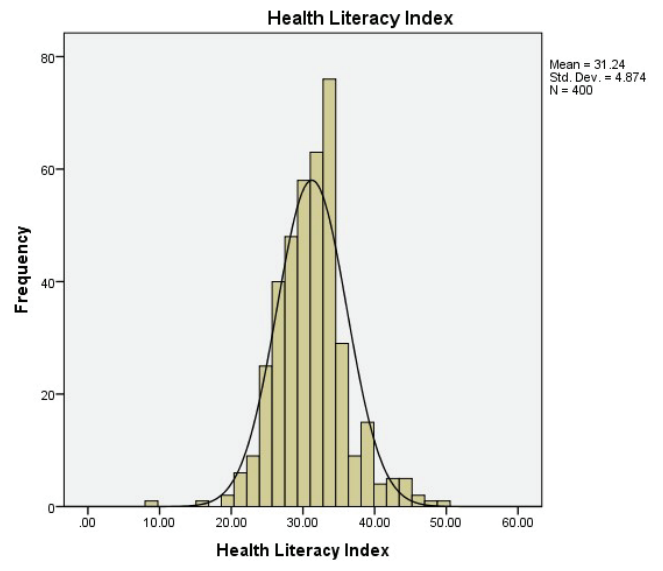

Fig. 1. Distribution of General Health Literacy Index scores among Respondents

Table 2. Distribution of Index of Each Domain of Health Literacy based on HLS-EU-Asia-Q (Range 0-50)

\begin{tabular}{|l|l|}
\hline Health Domain of Health Literacy & Mean[SD] \\
\hline Disease Prevention & $30.4[6.1]$ \\
\hline Health Care & $32.2[4.6]$ \\
\hline Health Promotion & $31.0[5.9]$ \\
\hline General Health Literacy & $31.2[4.9]$ \\
\hline
\end{tabular}

A total of $78.8 \%$ of respondents $(\mathrm{N}=400)$ admitted receiving "quite complete" drug information while they were filling prescriptions or consulting with the pharmacists. The distribution scores of drug information received from pharmacists is shown in Fig. 2.

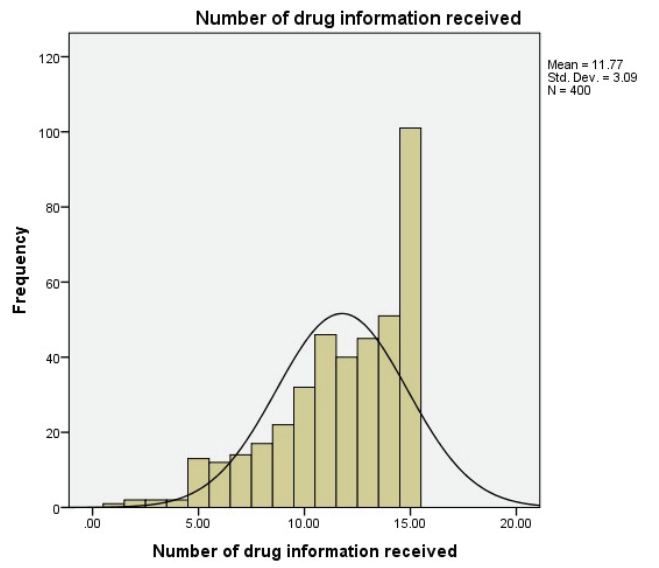

Fig. 2. Distribution scores of Drug Information Received from Pharmacists. 


\section{Discussion}

Almost two-thirds of the participants had limited health literacy indexes when measuring general health literacy with the HLS-EU-Asia-Q (Fig. 1). It was consistent with previous studies in Indonesia [10-13]. Small differences were found in the index scores of each health literacy domain, with disease prevention the lowest (Table II). Therefore, health knowledge needs to be increased among the adult population in Yogyakarta City, with special emphasis on disease prevention programs.

The HLS-EU-Asia-Q is a comprehensive tool for the health literacy survey that has been validated in Asia [7]. It assesses four information-processing domains (finding, understanding, judging, and applying) and three health domains (health care, disease prevention, and health promotion), which cover a broader concept of health literacy in populations and communities [14]. It was suggested to use the same tool to assess health literacy in Asia to provide comparisons within or between countries in the future [7].

Some sociodemographic factors which are associated with lower health literacy (female, age $\geq 65$ years, having long term illness, lower income and lower education) [15] were not statistically significant for predicting lower health literacy in this study $(\mathrm{p}>0.05)$. Several similar studies have also failed to prove the influence of sex, age, education, and income on health literacy, although many theories support the influence of sociodemographic characteristics on health literacy [1620].

Still, the amount of drug information received by patients is significantly different for respondents with limited health literacy indices $(\mathrm{p} \leq 0.05)$. The authors suggest that patients with complete information about their medications will be better informed and thus more likely to make the right health decisions, and thus better health literacy scores.

When there is association between the amount of drug information received and health literacy index scores, it is possible to optimize the content of drug information to patients to improve health literacy. Though there are many factors to be taken into account in designing the appropriate interventions, education and provision of drug information can be one of the most effective interventions to improve health literacy.

The high percentage of respondents who have received a sufficient amount of drug information indicates that pharmacists have been providing sufficient information to patients. Patients could remember that they actually received quite complete information about their medications. Unfortunately, the completeness of the information conveyed does not necessarily equate with patient comprehension of the medication.

Jacobson et al have proposed an intervention-area model for the improvement of health literacy that can be done by pharmacists (1). In cases where patients have limited levels of health literacy, pharmacists are not simply required to provide complete drug information, such as all items in the questionnaire, but to also emphasize face-to-face counseling. Pharmacists are actually encouraged to use literacy-sensitive techniques in providing drug information to patients. Literacysensitive techniques include the repetition of information by the patient, asking open questions, explanations using tools, demonstrations of drug use, using print materials [21], and the provision of treatment cards that help patients remember drug use rules (1). Surely this should be supported by facilities, whether in their pharmacies or pharmacy installations, as well as trained pharmacists to provide treatment information to patients with limited health literacy.

Since communication with pharmacists before patients receive medication is the last gate to ascertain whether they truly understand their condition and treatment plans, the role of pharmacist becomes extremely important in helping patients achieve optimal health outcomes and prevent medication errors. This can be accomplished if the pharmacists are able to tailor health information services to the patients' health literacy levels.

This study had limitations. The amount of drug information was used as a proxy to drug information services. That required not only sufficient quantity but also quality of communication. Therefore, the amount of drug information provided might not accurately describe the medication knowledge possessed by patients. Subsequently, there might be bias because of selfreporting questionnaires. Positive or negative answers might be affected by patients' feelings when answering the questionnaire.

Finally, the sample size was relatively small compared to national surveys, with a non-random sampling method that can affect the generalizability of the study. Thus, the results of this study should not be interpreted as results from national survey.

\section{Conclusion}

Pharmacists are no longer required to simply provide complete drug information. They are now also encouraged to offer face-to-face counseling using a literacy-sensitive technique for providing drug information to patients. The study complements health literacy index data from Yogyakarta City, Indonesia, which could serve as a basis for tailoring effective interventions to improved health literacy and outcome. Evidence of the amount of drug information received as a potential health literacy determinant is also provided.

This work was funded by Research Grant 2016 from Faculty of Pharmacy Universitas Gadjah Mada, Indonesia. The HLSEU-Asia-Q license was obtained from Universitas Gadjah Mada.

\section{References}

1. Carlisle, A., Jacobson, K.L., Di Francesco, L., Parker, R.M.: Practical strategies to improve communication with patients. Pharm. Ther. 36, $576(2011)$

2. Baker, D.W.: The meaning and the measure of health literacy. J. Gen. Intern. Med. 21, 878-883 
(2006). https://doi.org/10.1111/j.15251497.2006.00540.x

3. Nutbeam, D.: The evolving concept of health literacy. Soc. Sci. Med. 67, 2072-2078 (2008). https://doi.org/10.1016/j.socscimed.2008.09.050

4. Gazmararian, J., Jacobson, K.L., Pan, Y., Schmotzer, B., Kripalani, S.: Effect of a Pharmacy-Based Health Literacy Intervention and Patient Characteristics on Medication Refill Adherence in an Urban Health System. Ann. Pharmacother. 44, 80-87 (2010). https://doi.org/10.1345/aph.1m328

5. Zullig, L.L., McCant, F., Melnyk, S.D., Danus, S., Bosworth, H.B.: A health literacy pilot intervention to improve medication adherence using Meducation ${ }^{\circledR}$ technology. Patient Educ. Couns. 95, 288-291 (2014). https://doi.org/10.1016/j.pec.2014.02.004

6. Menteri Kesehatan Republik Indonesia. Peraturan Menteri Kesehatan Republik Indonesia Nomor 72 Tahun 2016 Tentang Standar Pelayanan Kefarmasian di Rumah Sakit. 2016 [cited 2019 Sep 11]. Available from: http://farmalkes.kemkes.go.id/?wpdmact=process $\&$ did=NDA5LmhvdGxpbms $=$

7. Duong, T. V, Aringazina, A., Baisunova, G., Nurjanah, Pham, T. V, Pham, K.M., Truong, T.Q., Nguyen, K.T., Oo, W.M., Mohamad, E., Su, T.T., Huang, H.-L., Sørensen, K., Pelikan, J.M., den Broucke, S. Van, Chang, P.W.: Measuring health literacy in Asia: Validation of the $\{$ HLS $\}-\{E U\}-$ Q47 survey tool in six Asian countries. J. Epidemiol. 27, 80-86 (2017). https://doi.org/10.1016/j.je.2016.09.005

8. Osborne, R.H., Batterham, R.W., Elsworth, G.R., Hawkins, M., Buchbinder, R.: The grounded psychometric development and initial validation of the Health Literacy Questionnaire ( $\{\mathrm{HLQ}\}$ ). \{BMC \} Public Heal. 13, (2013). https://doi.org/10.1186/1471-2458-13-658

9. Menteri Kesehatan Republik Indonesia. Peraturan Menteri Kesehatan Republik Indonesia Nomor 73 Tahun 2016 Tentang Standar Pelayanan Kefarmasian Di Apotek [Internet]. 2016 [cited 2019 Sep 11]. Available from: http://farmalkes.kemkes.go.id/?wpdmact=process $\underline{\text { \&did=NDEwLmhvdGxpbms= }}$

10. Rohmah, A.L.: Hubungan antara Tingkat Literasi Kesehatan dengan Citra Tubuh dan Aktivitas Fisik pada Remaja di Kabupaten Sleman, (2015)

11. Safila, I., Guardian, Y.: Hubungan antara Tingkat Literasi Kesehatan dengan Diabetes Self-Care Activities pada Pasien Diabetes Mellitus Tipe 2 di Kabupaten Sleman. Universitas Gadjah Mada, Yogyakarta (2015).

12. Hidayati, A., Guardian, Y., Harry F.: Tingkat Literasi Kesehatan dan Kepatuhan Diet pada Penderita Diabetes Mellitus di Populasi Rural dan Urban. Universitas Gadjah Mada, Yogyakarta. (2015).
13. Novianty, A., Hadjam, M.N.R.: Literasi Kesehatan Mental dan Sikap Komunitas sebagai Prediktor Pencarian Pertolongan Formal. J. Psikol. 44, 50 (2017). https://doi.org/10.22146/jpsi.22988

14. Sørensen, K., den Broucke, S. Van, Pelikan, J.M., Fullam, J., Doyle, G., Slonska, Z., Kondilis, B., Stoffels, V., Osborne, R.H., Brand, H.: Measuring health literacy in populations: illuminating the design and development process of the European Health Literacy Survey Questionnaire ( $\{$ HLS $\}-$ \{EU\}-Q). \{BMC\} Public Heal. 13, (2013). https://doi.org/10.1186/1471-2458-13-948

15. Beauchamp, A., Buchbinder, R., Dodson, S., Batterham, R.W., Elsworth, G.R., McPhee, C., Sparkes, L., Hawkins, M., Osborne, R.H.: Distribution of health literacy strengths and weaknesses across socio-demographic groups: a cross-sectional survey using the Health Literacy Questionnaire (HLQ). \{MC Public Heal. 15, (2015). https://doi.org/10.1186/s12889-015-2056-Z

16. Pawlak, R.: Economic considerations of health literacy. Nurs. Econ. 23, 173 (2005)

17. Sørensen, K., and Stephan Van den Broucke, Fullam, J., Doyle, G., Pelikan, J., Slonska, Z., Brand, H.: Health literacy and public health: A systematic review and integration of definitions and models. \{BMC\} Public Heal. 12, (2012). https://doi.org/10.1186/1471-2458-12-80

18. Jovic-Vranes, A., Bjegovic-Mikanovic, V., Marinkovic, J.: Functional health literacy among primary health-care patients: data from the Belgrade pilot study. J. Public Health (Bangkok). 31, 490-495 (2009). https://doi.org/10.1093/pubmed/fdp049

19. Escobedo, W., Weismuller, P.: Assessing Health Literacy in Renal Failure and Kidney Transplant Patients. Prog. Transplant. 23, 47-54 (2013). https://doi.org/10.7182/pit2013473

20. Baisunova, G.S., Turdaliyeva, B.S., Tulebayev, K.A.: Study of health literacy and health behavior in Almaty City and Almaty Region, Kazakhstan. Eur. J. Public Health. 26, (2016). https://doi.org/10.1093/eurpub/ckw175.020

21. Praska, J.L., Kripalani, S., Seright, A.L., Jacobson, T.A.: Identifying and Assisting Low-Literacy Patients with Medication Use: A Survey of Community Pharmacies. Ann. Pharmacother. 39, 1441-1445 (2005). https://doi.org/10.1345/aph.1g094

22. Widyakusuma, N.N.: Health Literacy Yogyakarta 2016 [Internet]. 2018 [cited 2019 Sep 11]. Available from: http://dx.doi.org/10.17632/rz389jcvz3.1 